\title{
PERAN TARUNA AKADEMI MILITER YOGYAKARTA DALAM MEMPERTAHANKAN KEMERDEKAAN INDONESIA (1945-1946)
}

\author{
Kuswono \\ Pendidikan Sejarah FKIP Universitas Muhammadiyah Metro \\ Email: Kromowijoyo@gmail.com
}

\begin{abstract}
Abstrak
Penelitian ini menggunakan metode historis dengan langkah pengumpulan sumber, kritik sumber, penafsiran dan sintesis (penulisan hasil penelitian). Hasil penelitian ini yakni peran taruna akademi militer begitu vital dalam mempertahankan kemerdekaan Indonesia. Pada keadaan kekurangan tentara terdidik dan terlatih, Taruna Akademi Militer yang ketika itu berkedudukan di Yogyakarta tampil sebagai kekuatan baru. Walaupun tidak dapat dipungkiri pengalaman mereka yang masih kurang dalam medan pertempuran menjadi pengalaman baru, pendidikan perang yang langsung dialami menempa jiwa-jiwa muda Taruna Akademi Militer. Setidaknya mereka pernah terlibat pada peristiwa-peristiwa penting seperti Peristiwa 10 November 1945 di Surabaya, Pengawal Jenderal Sudirman tahun 1946, Menjadi Panitia Oentoek Pengangkoetan Jepang dan APWI (POPDA), Pertempuran di Subang Tahun 1946.
\end{abstract}

Kata kunci: Taruna, Akademi Militer Yogyakarta, Kemerdekaan, Indonesia

\begin{abstract}
This study uses historical method with the step pengumlan source, source criticism, interpretation and synthesis (writing research results). The result of this research is that the role of military academy cadets is so vital in maintaining Indonesian independence. In the case of a shortage of trained and trained soldiers, the Military Academy Taruna, then based in Yogyakarta, emerged as a new force. While it is undeniable that their less-thanlife experience in the field of battle becomes a new experience, the direct war education has forged the young souls of the Military Academy Taruna. At least they have been involved in important events such as the November 10, 1945 Incident in Surabaya, General Guard Sudirman in 1946, Became the Oentoek Committee of Japan and APWI (POPDA), the Battle of Subang in 1946.
\end{abstract}

Keywords: Taruna, Military Academy of Yogyakarta, Independence, Indonesia

\section{PENDAHULUAN}

Tidak lazim bila saat ini taruna akademi militer sudah ikut berperang pada saat sekarang. Umumnya taruna dalam sebuah akademi militer hanya bertugas untuk belajar dan berlatih, kemudian setelah lulus mereka ditugaskan untuk melakukan tugasnya masing-masing. Berbeda halnya dengan kondisi Taruna AM Yogyakarta tahun 1945-1950, ketika menjadi taruna mereka telah diterjunkan untuk perjuangan mempertahankan kemerdekaan Indonesia. Selain mendapat pengetahuan dari materi yang diajarkan, mereka juga mendapatkan pengalaman yang jauh lebih berharga yakni terlibat langsung dalam kancah perang kemerdekaan baik melawan Inggris, maupun melawan Belanda. Teori dan praktek yang mereka dapatkan di akademi bisa langsung diterapkan dalam pertempuran.

Sangat jarang sebuah akademi sebagai lembaga pendidikan militer yang ikut serta aktif dalam perang. Kehadiran 
akademi militer dengan para taruna ditengah-tengah rakyat yang memanggul senjata selalu memberikan kebesaran hati dan dukungan moril yang tidak kecil artinya. Sikap pantas dan disiplin yang tepat menimbulkan rasa simpati rakyat. Djatikusumo mengatakan bahwa akademi militer dengan pasukan taruna adalah bagian dari TNI. Pertempuran dahsyat dalam periode kemerdekaan banyak memakan korban dari pihak taruna yang membuat rakyat semakin hormat kepada pengorbanan taruna. Hal itu membuktikan bahwa Taruna AM Yogyakarta bukanlah sekedar calon-calon perwira yang pandai mengumpulkan angka-angka tinggi dalam ujian akademis mereka, tetapi juga lulus cumlaude dalam ujian dimedan perang (Djtikusumo, 1977: xi).

Perang adalah perkelahian antara dua negara, Clausewitz berpendapat perang itu adalah sambungan dari jalan politik dengan lain cara. Kepandaian berperang dapat dipelajari dari sekolah-sekolah perwira dimana diajarkan seni juda, ilmu perang, strategi dan teknik (Adi Negoro. Tanpa Tahun: 287). Apabila perang itu terjadi cukup lama, pertimbangan kekuatan yang ada pada awalnya dapat berubah, bahkan tujuan perang itu sendiri dapat mengalami perubahan (Effendi Muchtar, dkk., 2009: 165).

Menurut Djatikusumo, perang mempertahankan kemerdekaan adalah perang besar, perang total. Perang total Indonesia adalah perang yang menentukan adanya bangsa Indonesia, kebudayaannya serta negaranya. Oleh karena itu, perang ini didukung oleh segenap komponen bangsa Indonesia. Adanya tuntutan untuk perang maka setiap prajurit harus menganal seni perang dan mempunyai kemampuan serta kesanggupan untuk perang (Effendi Muchtar, dkk., 2009: 165). Taruna AM Yogykarta telah ikut berjuang mempertahankan kemerdekaan RI. Mereka terlibat dalam peristiwa 10 November di Surabaya, penumpasan PKI di Madiun, melawan Sekutu di daerah Jawa Barat, perang gerilya, dan sebagainya.

\section{METODE PENELITIAN}

Penelitian ini menggunakan metode historis dengan langkah-langkah yakni pertama, heuristik. Pada tahap ini penulis melakukan pengumpulan berbagai sumber data baik berupa buku, jurnal, koran dan yang lainnya yang menunjang pada tema penelitian. Kedua kritik sumber, pada tahap ini dilakukan pemilihan data atau sumber yang relevan dengan tema. Kritik dilakukan dua tahap yakni kritik ekstern dan kritik intern. Kemudian tahap yang ketiga yakni interpretasi yakni penafsiran data-data otentik dan kredibel untuk mendapatkan sebuah narasi sejarah berdasarkan pada fakta dan data yang diperoleh. Langkah 
terakhir yakni sintesis atau penulisan hasil penelitian.

\section{HASIL DAN PEMBAHASAN}

Penelitian ini fokus pada Peranan

Taruna Akademi Militer Yogyakarta Sebelum Perang Kemerdekaan yakni tentang peran taruna dalam Peristiwa 10 November 1945 di Surabaya, Pengawal Jenderal Sudirman tahun 1946, Menjadi Panitia Oentoek Pengangkoetan Jepang dan APWI (POPDA), serta keterlibatan Taruna Akademi Militer dalam Pertempuran di Subang Tahun 1946.

\section{Peristiwa 10 November $1945 \mathrm{di}$ \\ Surabaya}

Kekalahan pasukan Jepang oleh Sekutu mengakibatkan seluruh jajahan Jepang jatuh ketangan Sekutu. Pelabuhan-pelabuhan di Indonesia didatangi oleh pihak Sekutu (Inggris) dengan alasan untuk melucuti senjata Jepang. Pasukan Inggris yang mendarat di Surabaya adalah Bridgade ke-49, divisi 23 India, dibawah komando Brigadir A.W.S. Mallaby. Kekuatannya sekitar 4000 orang yang terbagai dalam Batalyon Mahrattas dan Batalyon Rajputana Rifles. Kedatangan pasukan Inggris ke Indonesia membawa sebuah misi untuk melucuti senjata pasukan Jepang. Sebelum pasukan sekutu datang ke wilayah Indonesia untuk melucuti senjata pasukan Jepang, tentara bersama rakyat Surabaya telah berhasil mendapatkan senjata dari pasukan Jepang. Mayjen Mustopo dari pihak Republiktelah berunding dengan Jenderal Iwabe supaya Pasukan Jepang Menyerahkan senjatanya kepada pihak Republik. Hal tersebut disetujui oleh pihak Jepang pada tanggal 10 Oktober 1945 (Parakitri, 1981: 59). Mereka tergabung dalam Allied Forces Netherlands East-Indies (AFNEI). Tugas mereka adalah:

a. Menerima penyerahan pasukan Jepang.

b. Membebaskan tawanan perang dan tahanan Sekutu.

c. Melucuti, mengumpulkan dan memulangkan serdadu Jepang.

d. Menegakan dan mempertahankan keadaan untuk kemudian diserahkan kepada pemerintah sipil masingmasing.

e. Mengumpulkan keterangan tentang dan menuntut penjahat perang, dimuka pengadilan.

Awalnya pendaratan AFNEI di Jakarta, Surabaya, dan Semarang tidak diganggu gugat. Hal itu berdasarkan atas perintah menteri pertahanan Amir Syarifuddin yang memberikan kawat kepada pimpinan TKR di setiap daerah agar para pejuang mendukung misi Sekutu diatas (Daud Sinjal dan Atmadji Sumarkidjo, 2009: 76). Kecurigaan rakyat mulai timbul ketika melihat terdapat pasukan Belanda Netherlands Indies Civil 
Administration (NICA) yang bergabung dalam pasukan Sekutu. NICA membuka markas besar tentara Belanda di Jakarta. Kepercayaan rakyat Indonesia semakin hilang ketika pasukan NICA banyak melakukan kerusuhan di Jakarta. Sejak itu terjadi permusuhan antara Tentara Indonesia dengan Sekutu. Akibatnya adalah sering terjadinya insiden-insiden yang mengakibatkan bentrokan fisik. Pendaratan pasukan AFNEI di Surabaya pada 25 Oktober 1945 awalnya tidak dilawan oleh TKR. Kemarahan TKR terjadi ketika pasukan Sekutu secara tiba-tiba melepaskan pasukan Belanda yang ditawan oleh pemuda dan menyebarkan surat selebaran dari udara yang berisi tuntutan kepada Tentara Republikuntuk menyerahkan senjata kepada pihak Sekutu. Hal tersebut tentu saja membuat Tentara Republikdan badan-badan kelaskaran merasa tersinggung dan melakukan penyerangan terhadap pasukan Sekutu (Moehkardi, 1977: 52).

Perseteruan antara Sekutu dan pejuang Republiksemakin tajam ketika Mallaby sebagai pimpinan pihak Sekutu tewas dalam sebuah inseden di depan Gedung Internatio. Pasukan Inggris menuduh pihak Indonesia harus bertanggungjawab atas meninggalnya Mallaby. Mengenai Mallaby, Tom Driberg seorang anggota partai buruh yang pernah berkunjung ke Indonesia mengatakan bahwa Mallaby terbunuh dalam pertempuran setelah terjadi gencatan senjata. Pasukan Sekutu dan pasukan Republikyang tidak tahu mengenai gencatan senjata tersebut terlibat kontak senjata. Ketika Mallaby keluar dari Gedung Internatio berteriak kepada Sekutu untuk menghentikan tembakan kearah pasukan Republik, namun beberapa saat setelah itu Mallaby kembali meneriakkan untuk kembali menembak kearah pasukan Republik. Sekutu melepaskan tembakan dengan 20 senapan dan mesin Bren, mendapat serangan seperti itu Pasukan Republikmundur mencari tempat perlindungan. Dalam suasana seperti ini Mallaby meninggal. Tom Driberg mengatakan.

"... soedah djelas sekali, bahwa sedjak saat ia memberi perintah oentoek melepaskan tembakan, perdjanjian peletakan senjata soedah berachir, setidak-tidaknja ditempat itoe... beloemlah dapat dipastikan apakah Mallaby ditewaskan oleh orang Indonesia atau oleh geranat jang dilemparkan seorang opsir India kearah orangorang Indonesia, jang mendekati mobilnya."( Koran Merdeka Tanggal 22 Februari 1946)

Pasukan Sekutu kemudian mendatangkan lagi pasukan divisi 5 dibawah pimpinan E.C. Mansergh. Kekuatan tentara Sekutu semakin kuat, pada 9 November 1945 Mansergh mengeluarkan ultimatum yang ditujukan kepada pimpinan dan rakyat Surabaya. Isi dari ultimatum tersebut adalah perintah untuk menyerahkan senjata 
kepada pasukan Sekutu, apabila ultimatum tersebut tidak diindahkan oleh pihak Republikmaka Sekutu akan melakukan tindakan militer keesokan harinya. Pihak Republik tidak menanggapi hal tersebut maka pada 10 November 1945 Mansergh memutuskan untuk menyerang Surabaya dari darat, laut dan udara.

Pada bulan November itu juga merupakan awal dari para taruna menjalani kehidupan di AM Yogyakarta. Mendengar pemberitaan mengenai pertempuran di Surabaya membuat tergugah hati para pemimpin $A M$ Yogyakarta. Terdapat permohonan dari Surabaya kepada MBT di Yogyakarta untuk mengirimkan sejumlah perwira yang mengerti mengenai senjata berat (meriam). Urip Sumoharjo mengutus Suwardi untuk berangkat ke Surabaya. Pimpinan AM Yogyakarta akhirnya memutuskan untuk mengirimkan Taruna AM Yogyakarta yang telah lulus ujian masuk untuk membentu perjuangan di Surabaya. Terdapat 23 taruna dan beberapa staf AM Yogyakarta yang dikirimkan. Rombongan langsung dipimpin Direktur AM Yogyakarta Mayjen Suwardi (Moehkardi, 1977:48).

Mayjen Suwardi berangkat lebih dulu dengan menggunakan mobil ke Surabaya. Rombongan AM Yogyakarta yang dipimpin oleh Sastrodiwirjo dan Pak Karto berangkat pada 11 November 1945 sekitar pukul 20.00 WIB, dengan kereta api menuju Surabaya. Tiba di stasiun Wonokromo 12 November sekitar pukul 14.00 WIB. Mereka bermalam di rumah dekat stasiun. Pada 13 November rombongan dipecah menjadi dua rombongan. Sebagian bertugas di markas perjuangan Surabaya, sebagian yang lain di Jalan Kaliasin No. 117 untuk bermalam. Hari-hari berikutnya banyak hal yang dilakukan oleh rombongan $A M$ Yogyakarta dari mulai mengamankan amunisi meriam kaliber 10,5 cm, Bren di Sawahan dekat dengan panti asuhan de Bosco. Kegiatan ini merupakan hari sial untuk taruna Sumarjo, kakinya terkena rantai traktor hingga harus dirawat di PMI Baluran (sekarang SMP 3 Jln. Praban) (Barlan Setiadijaya, 1992: 589).

Pada 16 November pasukan AM Yogyakarta mencoba melakukan stelling di Gunungsari percobaan penembakan hanya dilakukan dengan perkiraan. Akibatnya percobaan penembakan membahayakan pertahanan sendiri. Keesokan harinya setelah mendapatkan peta dan teropong (schaarkijker) dimulai lagi penembakkan tersebut. Penembakan Meriam begitu gencar membuat pasukan Inggris memusatkan perhatiannya ke daerah Gunungsari. Merasa mendapat serangan balik pasukan AM Yogyakarta dengan pimpinan bernama Dullah berusaha melakukan perpindahan ke daerah Kriyan (Barlan Setiadijaya, 1992: 589 ). 
Tabel 7. Taruna AM Yogyakarta yang Ikut Berjuang di Surabaya Tahun 1945

\begin{tabular}{|c|c|c|}
\hline No. & Nama & Jabatan \\
\hline 1. & Mayjen. Suwardi & Direktur AM Yogyakarta \\
\hline 2. & Sastrodiwirjo & Staf \\
\hline 3. & Karto & Staf \\
\hline 4. & Subroto & Taruna \\
\hline 5. & Harsojo & Taruna \\
\hline 6. & Sukardjono & Taruna \\
\hline 7. & Sukarsono & Taruna \\
\hline 8. & Marijo & Taruna \\
\hline 9. & Sudargo & Taruna \\
\hline 10. & Djoko Sudarsono & Taruna \\
\hline 11. & Bambang Pamungkas & Taruna \\
\hline 12. & Sofrin & Taruna \\
\hline 13. & Murtijono & Taruna \\
\hline 14. & Susanto & Taruna \\
\hline 15. & Prawiro Suseno & Taruna \\
\hline 16. & Pujiono & Taruna \\
\hline 17. & Purnonmo Harjo Dipo & Taruna \\
\hline 18. & Udoro & Taruna \\
\hline 19. & Sudarmo & Taruna \\
\hline 20. & Suwandi & Taruna \\
\hline 21. & Mudjiono & Taruna \\
\hline 22. & Prasetijo & Taruna \\
\hline 23. & Pamudi & Taruna \\
\hline 24. & Ngatidjo & Taruna \\
\hline 25. & Harsono & Taruna \\
\hline 26. & Darminto & Taruna \\
\hline
\end{tabular}

Sumber. Barlan Setiadijaya. (1992). 10 November 1945 Gelora Kepahlawanan Indonesia, Jakarta: Yayasan 10 November 1945, p. 590.

Setelah Beberapa pekan pertempuran antara Sekutu dan pihak Republiksemakin jarang. Pada pertengahan bulan Desember 1945, separuh pasukan AM Yogyakarta kemudian ditarik kembali ke Yogyakarta untuk mulai belajar di kampus Kotabaru. Separuh lagi masih membantu di Kriyan menunggu datangnya pergantian pasukan. Kelompok separuh kedua ini baru bisa kembali dan mendapatkan pelajaran di AM Yogyakarta pada Februari 1946 setelah kedudukannya di
Kriyan digantikan oleh TKR (Moehkardi, 1977: 59-60).

Untuk menyambut kedatangan pasukan AM Yogyakarta yang baru pulang dari medan perang di Surabaya maka pada tanggal 11 Desember 1945 diadakan malam gembira oleh para taruna. Pada malam itulah dinyayikan himne taruna. Menurut Moehkardi himne tersebut merupakan hasil dari lomba pembuatan lagu untuk AM Yogyakarta yang diselanggarakan melalui pers pada tanggal 13 November 1945. Pemenang 
dari lomba tersebut adalah R.A.J. Sujasmin dan mendapatkan uang sebesar Rp. 50,- (Moehkardi, 1977: 59-60). Sedangkan dalam buku Doorstoot Naar Djokja menyebutkan bahwa pencipta himne taruna versi awal karya Soebagja Oetama berbunyi.

Biar badan hancoer leboer,

Kita akan bertepoer,

Membela keadilan soetji,

Kebenaran moerni,

Di bawah dwiwarna pandji

Kita nan bakti,

Mengorbankan djiwa dan raga

Membela iboe pertiwi,

Demi Allah Maha Esa,

Kami nan sumpah,

Setia membela noesa dan bangsa,

Tanah toempah darah (Julius Pour, 2009: 91).

Terjadi kejanggalan dalam menetukan pencipta dari himne taruna tersebut. R.A.J. Sujasmin yang disebutkan oleh Moehkardi sebagai pencipta lagu tersebut ternyata tidak mau mengakui lagu tersebut lagu ciptaannya. Sedangakan Julius Pour mengatakan bahwa pencipta himne taruna versi awal adalah Soebagja Oetama. Syair lagu tersebut mempunyai makna yang dalam dan menyentuh apabila dihayati per kalimat dari himne tersebut. Lagu dinyayikan dengan irama Andente Religius yang isinya adalah janji dan sumpah para taruna untuk bertempur.

\section{Pengawalan Jenderal Sudirman Tahun 1946 \\ Bulan Oktober 1946 perundingan} Linggajati antara Indonesia-Belanda sudah mendekati tahap penyelesaian. Pada hari Minggu 20 Oktober 1946 dengan kereta api luar biasa Jenderal Sudirman dan Urip Sumoharjo pergi dari Yogyakarta menuju Jakarta. Diperjalanan menuju Jakarta tepatnya di daerah Klender diperbatasan wilayah kekuasaan RI dengan wilayah Belanda kereta api diberhentikan oleh pasukan Sekutu penjaga perbatasan. Pasukan Sekutu meminta supaya senjata para pengawal Sudirman disita dan pengawal melanjutkan perjalanan ke Jakarta tanpa persenjataan. Melihat kecongkakan pasukan Sekutu itu dengan nada tinggi Sudirman menolak. Sudirman menganggap hal itu merupakan kesewenang-wenangan dari pihak Belanda terhadap Indonesia.

"Tidak! tidak bisa begitu! Kita kembali ke Yogya saja kalau pengawal tidak boleh pakai senjata. Ini pelanggaran kehormatan terhadap panglima besar dan negara. Saya tidak mau ke Jakarta, kalau kehormatan tidak diberikan sebagaimana layaknya seorang panglima besar dari negara yang berdaulat dan merdeka" (Sukanto SA, 2000: 166).

Insiden tersebut dianggap sebagai suatu pelecehan yang dilakukan oleh Belanda terhadap kedaulatan Indonesia. 
Belanda tidak menghargai kedaulatan RI sehingga memperlakukan orang-orang Republik sebagai bawahannya. Sudirman menginginkan pengakuan kemerdekaan Indonesia oleh pihak Belanda, sehingga dalam perundingan harus diperlakukan selayaknya negara yang sederajat. Kereta api yang ditumpangi oleh Sudirman batal masuk ke Jakarta dan memilih untuk kembali ke Yogyakarta. Suasana menjadi tegang namun tidak sampai pada kontak senjata.

Kira-kira dua pekan setelah insiden tersebut Sudirman kembali ke Jakarta dengan pengawalan dari pasukan Republik. Sebanyak 30 orang mengawal Sudirman dengan senjata lengkap pergi mendampingi Sang Jenderal. Taruna AM Yogyakarta mendapat kehormatan untuk menjadi pengawal dari kedua pembesar tentara itu (Sukanto SA, 2000: 167). Pertimbangan untuk memilih pengawal dari Taruna AM Yogyakarta bisa jadi didasarkan pada tingkat kedispilinan dan intelektualitas dari para Taruna yang lebih tinggi dibandingkan dengan satuan yang lainnya, sehingga akan membawa gengsi tersendiri bagi bangsa Indonesia. Selain itu sebagai unjuk kekuatan angkatan perang Indonesia untuk menunjukan bangsa Indonesia mempunyai angkatan perang yang memadai. Selain pertimbangan diatas juga karena Taruna AM Yogyakarta banyak yang memiliki kemampuan bahasa Belanda dan bahasa Inggris yang cukup (Daud Sinjal, 68).

Taruna AM Yogyakarta yang ditunjuk menjadi pengawal diberi seragam yang bagus dan senjata yang lengkap. Moehkardi menyebutkan terdapat sekitar 15 taruna yang ditunjuk menjadi pengawal dan ditambah dari pasukan lain. Pengalaman pengawalan seorang petinggi angkatan perang sungguh merupakan tanggung jawab yang berat. Apalagi pengawalan untuk memsuki wilayah kekuasaan pihak Belanda. Pengawal langsung berhadapan dengan musuhnya sendiri (serdadu NICA). Ketika memasuki daerah Jakarta kedua belah pihak bersiap siaga menghadapi segala kemunginan. Rasa berdebar-debar pastinya ada, apalagi baru pertama kali ditugaskan seperti itu (Moehkardi, 1977: 73-74).

Kedatangan rombongan Sudirman ke Jakarta disambut oleh rakyat yang memang masih mencintai Republik Indonesia. Para pendukung RI berbondong-bondong mendatangi Stasiun Gambir untuk menyambut rombongan Sudirman. Perundingan gencatan senjata bertepatan dengan hari raya Idul Adha, sebagai sambutan bagi rakyat Jakarta maka Sudirman melakukan sholat Idul Adha bersama rakyat Jakarta di Lapangan Gambir (Lapangan Merdeka sekarang). Setelah itu baru hari-hari berikutnya Sudirman mengadakan perjanjian gencatan senjata yang 
dilaksanakan di Hotel Oranye jalan Majapahit.

Tugas para taruna

pengawal di Jakarta adalah menjaga rombongan Sudirman yang berkediaman sementara di Hotel Shutteraaf dekat stasiun Gambir. Hotel ini dijaga terus menerus oleh pasukan pengawal secara bergiliran. Ujian mental dari pasukan musuh yang menghina memang terjadi ketika para pengawal melakukan tugasnya. Disisi lain penduduk Jakarta yang ikut memantau juga merasa bangga terhadap pasukan Republikyang mempunyai disiplin tinggi (Moehkardi, 1977: 73-74).

\section{Menjadi Panitia Oentoek Pengangkoetan Jepang dan APWI (POPDA)}

Pasukan Inggris yang terus melakukan tekanan terhadap pasukan RI dengan melakukan serangan-serangan yang membuat Tentara Republiktidak bisa berbuat banyak kecuali bertahan mempertahankan kedaulatan RI. Dalam waktu yang singkat tentara Inggris telah menguasai kota-kota terkecuali kota Magelang dan Ambarawa. Pasukan Inggris mengalami kesulitan untuk menaklukan kedua kota itu. Mereka memilih mundur dan menetap di kota Semarang.

Menurut surat yang dikirimkan oleh Inggris kepada pihak Belanda bahwa Inggris akan mulai menarik pasukannya dari wilayah Indonesia pada bulan
November 1946. Pasukan Inggris begitu ingin meninggalkan Indonesia dan melepaskan peranan yang tidak menyenangkan itu. Mereka mendesak agara pihak Belanda mengadakan suatu persetujuan dengan pihak Republik. Desakan terwujud dengan diadakannya persetujuan Linggajati (G.M.T. Kahin: 1995: 246-247).

Bulan Agustus 1946 pasukan RI membantu memulangkan APWI (Allied Prisoners of War and Interneers) dan ekstentara Jepang dari wilayah RI ke daerah pendudukan Sekutu. Bantuan tersebut atas tawaran jasa yang diberikan oleh Syahrir kepada pihak Sekutu dengan membentuk POPDA (Panitia Oentoek Pengembalian Bangsa Jepang dan APWI). APWI sebagian besar adalah warga negara Belanda yang selama pendudukan Jepang menjadi tawanan Jepang. Pengawalan dilakukan oleh TRI dan pasukan Taruna AM Yogyakarta sebanyak 20 orang. Taruna AM Yogyakarta bertugas sebagai pengawal dan pengurus perjalanan. Diantara mereka yang ditunjuk ialah Sayidiman, Hario Mataram, Atwar Nurhadi, Abdul Muthalib, Syamsudin Noor, Sudarmo, Yusman Amir, dan Imam Koesnandir (Daud Sinjal, : 64).

Rata-rata yang bertugas di POPDA adalah orang yang menguasai bahasa Inggris dan bahasa Belanda. Bersama tawanan perang mereka diterbangkan dari Solo ke Semarang 
dengan pesawat Angkatan Udara Inggris (RAF) jenis DC-3. Pengangkutan APWI tidak hanya dilakukan dengan pesawat udara tapi juga dengan kereta api, dan kapal laut (Wahju Marsudi Wibowo, 2009: 31). Keadaan sangat tegang karena pasukan pengawal tidak dipersenjatai. Ada kekhawatiran jika pasukan pengawal akan disergap oleh Sekutu di Semarang. Pengawalan tersebut berakhir pada 19 Agustus 1946. Tiga hari kemudian mereka ditugaskan ke Front Subang.

\section{Pertempuran di Subang Tahun 1946}

Pertempuran antara Sekutu dengan tentara Indonesia terus terjadi diberbagai kota. Berbagai kelompok perjuangan melakukan kegiatannya mengusir penjajah keluar dari bumi Indonesia. Bandung yang ketika itu merupakan daerah sasaran Sekutu adalah daerah yang sangat rawan dengan pertempuran. Pasukan Sekutu ingin mempertahankan daerah antara JakartaBogor-Bandung sebagai lini pertahanan mereka. Hal tersebut memicu kemarahan tentara Indonesia, pertempuran sering terjadi di daerah Subang, Cianjur, Sukabumi, Bogor dan daerah sekitarnya.

Pertempuran di daerah Jawa Barat (Bandung Utara-Timur) mengikutsertakan dari korp Taruna AM Yogyakarta. Mereka ditugaskan di front Subang kurang lebih dua bulan. Penempatan pasukan Taruna AM
Yogyakarta merupakan kerjasama anatara pimpinan AM Yogyakarta Mayjen Suwardi dengan Mayjen Mustopo yang menjadi kepala staf komando Bandung Utara-Timur (Bratamenggala) sekaligus komandan Pasukan Teratai. Pengiriman pasukan tersebut merupakan bagian dari kurikulum yang dijalankan oleh $A M$ Yogyakarta agar taruna $A M$ mendapat pengalaman bertempur. Pasukan Taruna AM Yogyakarta sengaja tidak disatukan dengan pasukan TRI karena perbedaan pandangan antara komandan TRI dengan Suwardi. Satu-satunya langkah untuk tujuan itu adalah menitipkan pasukan taruna kepada Mustopo dan beliau setuju. Penerjunan pasukan AM Yogyakarta ke Front Subang disetujui pula oleh menteri pertahanan Amir Syarifudin dan staf umum Urip Sumoharjo (Moehkardi, 1977: 68).

Terdapat dua gelombang pasukan AM Yogyakarta yang dikirimkan ke front Subang. Gelombang pertama berangkat kira-kira pertengahan bulan Juli 1946 jumlah taruna kurang lebih satu kompi. Beberapa bulan kemudian dikirim gelombang kedua untuk menggantikan taruna gelombang pertama. Taruna yang berangkat pada gelombang kedua ditarik dari Front Subang pada pertengahan Oktober 1946 (Moehkardi, 1977: 68). Pasukan taruna disebar dalam kelompok kecil yang terdiri dari 2-3 orang, masingmasing memimpin satu peleton atau satu regu pasukan yang ditempatkan di pos- 
pos terdepan pertahanan. Pos-pos yang ditempati oleh Taruna AM Yogyakarta di antaranya pos Bukanegara, Cikawari, Cikareot, Cibereum, puncak Eurat.

Taruna AM Yogyakarta dipercaya juga menjadi komandan peleton seperti Subroto menjadi pimpinan di Bukanegara, sedangkan Himawan Sutanto menjadi pemimpin Barisan Maling yang berhasil menurunkan bendera Belanda di Puncak Eurat. Barisan Maling adalah sekelompok orang bekas pencuri yang dibina menjadi satu kelompok perjuangan yang dimanfaatkan sebagai kelompok pengacau kepada pihak musuh (Daud Sinjal, 274). Selain barisan maling terdapat juga Barisan Wanita P (penghibur). Barisan wanita tersebut bertujuan untuk memperlemah moral dari pasukan musuh sekaligus menyebarkan penyakit kotor. Keberadaan barisan tersebut ternyata membawa hal yang positif dan negatif bagi kubu pasukan RI. Tidak jarang barisan maling merampok harta benda rakyat yang berada disekitar daerah operasi, sedangkan barisan wanita tidak hanya pasukan musuh yang menjadi sasaran meraka tetapi pasukan RI ikut menjadi pelanggan dari barisan wanita tersebut. Sedangkan yang lainnya membantu dibagian staf komando Bratamenggala. Selama pasukan taruna ditugaskan di Front Subang terdapat satu orang taruna yang hilang bernama Jaya. Jaya menghilang ketika terjadi pertempuran antara pasukan RI dengan pasukan Jepang yang diperintahkan oleh pihak Sekutu (Daud Sinjal, 109-110).

\section{PENUTUP}

$\mathrm{Di}$ tengah keterbatasan masa revolusi fisik tidak pernah hilang peran besar seluruh komponen lapisan masyarakat baik itu masyarakat sipil maupun militer bahu membahu mempertahankan kemerdekaan yang baru diperolehnya. Terkuras tenaga dan pikiran bahkan sampai pada pengorbanan nyawa maka sepantasnya generasi saat ini menjadikan peristiwa-peristiwa tersebut sebagai pembelajaran untuk menyongsong Indonesia yang lebih maju. Namun, terkadang peran mereka (para pahlawan) terlupakan demi kepentingan golongan, politik, ambisi berkuasa. Korupsi disana-sini. Tentu mencederai perjuangan para pahlawan kita. Jangan melupakan sejarah, dan selalu belajar dari sejarah.

\section{DAFTAR PUSTAKA}

Adi Negoro. Tanpa Tahun. Ensikolopedi Umum dalam Bahasa Indonesia, Jakarta: Bulan-Bintang.

Barlan Setiadijaya. (1992). 10 November 1945 Gelora Kepahlawanan Indonesia, Jakarta: Yayasan 10 November 1945.

Daud Sinjal dan Atmadji Sumarkidjo. (2009). Himawan Soetanto Menjadi TNI, Jakarta: Katahasta.

Djtikusumo, (1977). Kata Pengantar", dalam Moehkardi."Akademi Militer 
dalam Perjuangan Pisik 1945-1949"

Yogyakarta: Inaltu.

Effendi Muchtar, dkk. (2009). GPH Djatikusumo Sosok Parjurit Sepi Ing Pamrih Rame Ing Gawe, Bandung: Dinas Sejarah Angkatan Darat, 2009, hlm. 165.

G.M.T. Kahin, "Nationalism and Revolution in Indonesia", a.b. Nin Bakdi Soemanto. (1995). Refleksi Pergumulan Lahirnya Republik: Nasionalisme dan Revolusi di Indonesia, Jakarta: UNS Press\&Pustaka Sinar Harapan.

Julius Pour. (2009). Doorstoot Naar

Djokja: Pertikaian Pemimpin SipilMiliter, Jakarta: Kompas.

Koran Merdeka. (1946). “Mallaby Tidak dibunuh, la Tewas dalam Pertempuran: Keterangan Tom Driberg." Koran merdeka Tanggal 22 Februari 1946.

Kuswono, K. (2016). Pembentukan Akademi Militer Yogyakarta 19451950. ISTORIA, 11(2).

Parakitri. (1981). Kusni Kasdut, Jakarta: Gramedia.

Sukanto SA. (2000). "Perjalanan Bersahaja Jenderal Sudirman" dalam Sardiman, Panglima Besar Jenderal Sudirman Kader Muhammadiyah, Yogyakarta: Adicita Karya Nusa.

Wahju Marsudi Wibowo. (2009). "TKR/TRI dan POPDA", Majalah Senakatha Edisi Desember 2009, Jakarta: Pusat Sejarah TNI. 